\title{
Karakteristik Mangan (Mn) di Daerah Kliripan dan Sekitarnya, Desa Hargorejo, Kecamatan Kokap, Kabupaten Kulon Progo, Propinsi Daerah Istimewa Yogyakarta
}

\author{
Agus Harjanto $^{1^{*}}$ \\ ${ }^{1}$ Jurusan Teknik Geologi , Fakultas Teknologi Mineral, Universitas Pembangunan Nasional "Veteran” \\ Yogyakarta
}

\begin{abstract}
Abstrak
Daerah Kliripan secara administrasi terletak di Desa Hargorejo, Kecamatan Kokap, Kabupaten Kulon Progo, D.I.Yogyakarta . Secara geografis daerah telitian berada pada $110^{\circ} 10^{\prime} 00^{\prime \prime}$ BT - $110^{\circ} 16^{\prime} 02^{\prime \prime}$ BT dan $7^{\circ} 40^{\prime} 05^{\prime \prime} \mathrm{LS}-7^{\circ} 52^{\prime} 10^{\prime}$ ' LS, dengan luas $6 \times 7 \mathrm{~km}^{2}$. Penelitian ini mempunyai tujuan untuk mengetahui karakteristik mangan di daerah Kliripan dan sekitarnya. Metodologi yang digunakan adalah pengambilan sampel di lapangan kemudian dianalis laboratorium petrografi untuk mengetahui komposisi mineral batuan dan analisis AAS (Atomic Absorption Spectometr) untuk mengetahui kadar mangan. Geologi daerah telitian didominasi batuan vulkanik dan batugamping berumur Oligosen Akhir-Pliosen. Stratigrafi daerah telitian dari tua ke muda adalah Formasi Nanggulan, Formasi Kaligesing/Dukuh, Formasi Jonggrangan, Formasi Sentolo, Endapan Alluvial. Formasi Kaligesing/Dukuh di beberapa tempat diterobos oleh diorit, andesit, dan dasit. Mineralisasi mangan ditemukan di daerah Kliripan dan Ngargoretno di Formasi Jonggrangan pada batugamping terumbu dan sisipan batugamping klastik. Karakteristik mangan di daerah Kliripan ada 2 macam yaitu nodulnodul di batugamping Formasi Jonggrangan dan mangan berlapis sebagai sisipan batugamping klastik. Mineralisasi mangan di daerah Kliripan berasosiasi dengan pirolusit, manganit, psilomelan dan rodhokrosit. Hasil analisis AAS kandungan mangan di daerah Kliripan berkisar antara 45,1\% sampai $63,1 \%$. Mineralisasi mangan di daerah Kripan termasuk dalam mangan sedimen.
\end{abstract}

Kata kunci : Formasi Jonggrangan; mangan berlapis; mangan sedimen; nodul.

\begin{abstract}
The research area is administratively located in Kliripan, Hargorejo Village, Kokap District, Kulon Progo Regency, Yogyakarta Special Region. Geographically, the research area is at $110^{\circ} 10^{\prime} 00^{\prime \prime}$ $110^{\circ} 16^{\prime} 02^{\prime \prime}$ and $7^{\circ} 40^{\prime} 05^{\prime \prime}-7^{\circ} 52^{\prime} 10^{\prime \prime}$, with an area of $6 \times 7 \mathrm{~km} 2$. This study aims to determine the characteristics of manganese in the Kliripan area and its surroundings. The methodology used is by taking samples of the representative rock and analyzing its petrographic properties to determine the composition of rock minerals. In addition, the Atomic Absorption Spectometr (AAS) analysis was also carried out to determine the level of manganese. The geology of the research area is dominated by volcanic rocks and limestone Late Oligocene-Pliocene ages. The stratigraphy of the research area from old to young is the Nanggulan Formation, the Kaligesing / Dukuh Formation, the Jonggrangan Formation, the Sentolo Formation, Alluvial Deposits. The Kaligesing / Dukuh Formation in several places is penetrated by diorite, andesite and dacite. Manganese mineralization is found in the Kliripan and Ngargoretno areas in the Jonggrangan Formation on reef limestones and clastic limestone intercalation. There are 2 types of manganese characteristics in the Kliripan area, nodules in the limestone of the Jonggrangan Formation and there is also layered manganese as an intercalating beds in clastic limestone. Manganese mineralization in the Kliripan area is associated with pyrolusite, manganite, psilomelan and rodhocrocyte. Based on AAS analysis, the manganese content in the Kliripan area ranged from $45.1 \%$ to $63.1 \%$. Manganese mineralization in the Kripan area is concluded as sedimentary manganese.
\end{abstract}

Keywords: Jonggrangan Formation; layered langanese; sedimentary manganese; nodule.

\footnotetext{
*Korespondensi: aharjanto69@upnyk.ac.id

Diajukan : 9 November 2020

Diterima : 1 Desember 2020

Diterbitkan : 31 Maret 2021
} 


\section{PENDAHULUAN}

Daerah telitian termasuk ke dalam wilayah Pegunungan Progo Barat yang secara fisiografi merupakan suatu kubah dengan puncaknya yang relatif datar dan sisi-sisinya yang terjal. Pegunungan Progo di sebelah utara dan timur di batasi oleh lembah sungai Progo. Dataran endapan alluvial pantai merupakan batas selatannya, sedangkan di sebelah barat Pegunungan Progo ini dibatasi oleh dataran rendah Purworejo. Secara administrasi daerah telitian terletak di daerah Kliripan dan sekitarnya, Desa Hargorejo, Kecamatan Kokap, Kabupaten Kulon Progo merupakan perbatasan Kabupaten Kulon Progo, Propinsi Daerah Istimewa Yogyakarta. Letak geografis daerah telitian $110^{\circ} 10^{\prime} 00^{\prime \prime} \mathrm{BT}-110^{\circ} 16^{\prime} 02^{\prime \prime}$ BT dan $7^{\circ} 40^{\prime} 05^{\prime \prime} \mathrm{LS}-7^{\circ} 52$ ' $10^{\prime}$ " LS, dengan luas $6 \times 7$ $\mathrm{km}^{2}$ (Gambar 1).

Pegunungan Kulon Progo merupakan daerah tinggian yang terletak dalam zona poros pematang menurut pembagian Lemigas (1972 dalam Sujanto dan Roskamil, 1975). Sejumlah tinggian dan rendahan dapat dibedakan pada poros ini, yaitu Tinggian Kulon Progo, Tinggian Kebumen, Tinggian Karangbolong, Tinggian Gabon dan Tinggian Besuki. Tinggian-tinggian dan rendahan-rendahan pada umumnya dibatasi oleh sesar-sesar bongkah dengan throw relatif besar.

Berdasarkan penanggalan radiometri K-Ar oleh (Atmadja, dkk, 1991) bahwa umur batuan volkanik tersebut $42.73 \pm 9.78$ sampai $15.30 \pm$ 0.88 juta tahun yang lalu (Oligosen - Miosen). Rahardjo, dkk, 1995 telah memetakan peta geologi lembar Yogyakarta skala 1: 100.000 (Gambar 2).

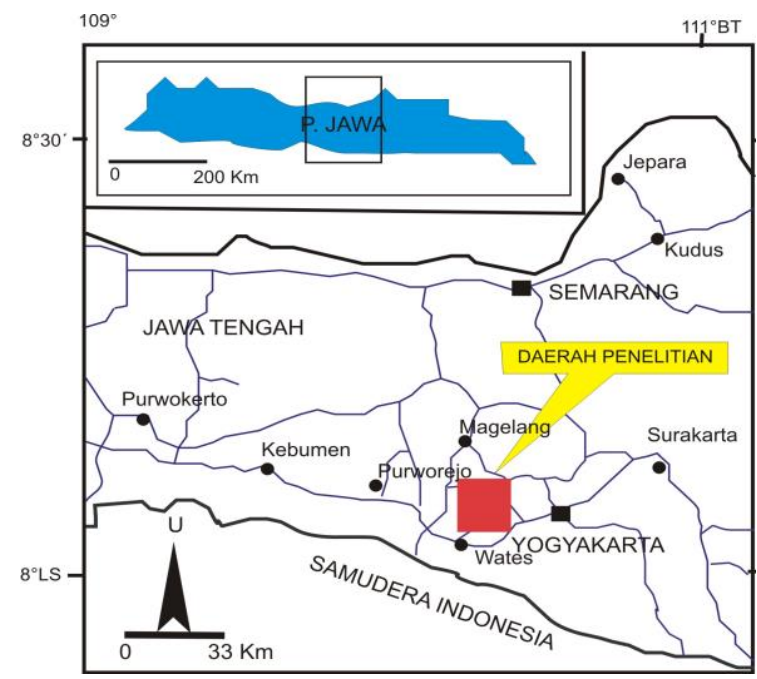

Gambar 1. Lokasi Daerah Penelitian.

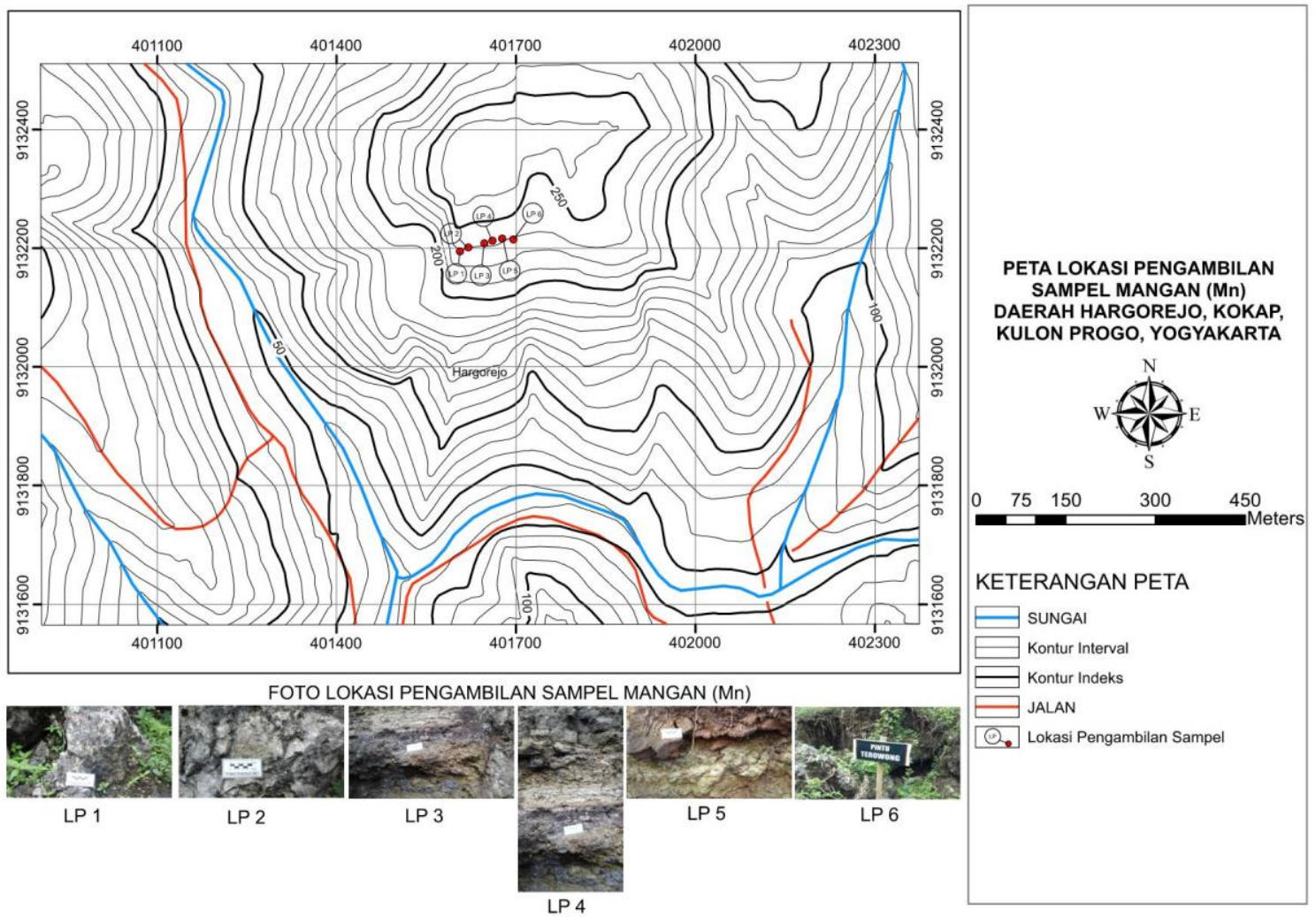

Gambar 2. Peta Lokasi Pengambilan Sampel Mangan (Mn) Daerah Telitian 


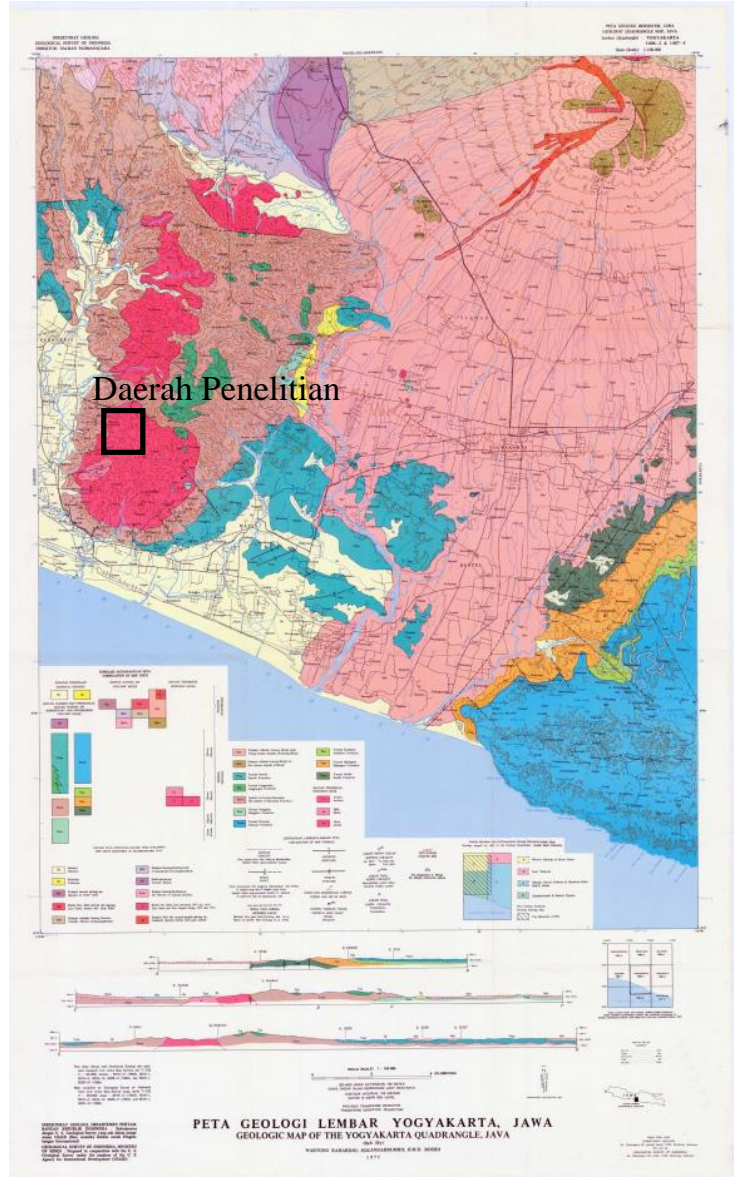

Gambar 3. Peta Geologi Regional menurut Rahardjo,dkk (1995).

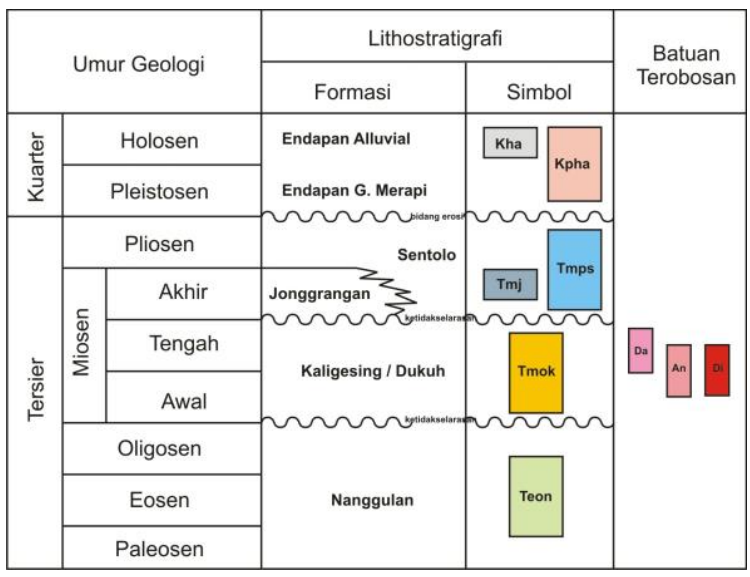

Gambar 4. Stratigrafi Daerah Penelitian.

Secara regional satuan Litostratigrafi dari umur tua ke muda adalah Formasi Nanggulan, Formasi Kaligesing, Formasi Dukuh, Formasi Jonggrangan, Formasi Sentolo serta endapan gunung api Kuarter dan endapan alluvial. Di atas Formasi Andesit Tua diendapkan secara tidak selaras Formasi Jonggrangan dan Formasi Sentolo. Formasi Jonggrangan dicirikan oleh napal tufaan dan batupasir gampingan dengan sisipan lignit. Di bagian atas berubah menjadi batugamping berlapis dan batugamping terumbu Daerah Kulon Progo merupakan daerah dataran tinggi yang dibatasi oleh tinggian Kebumen, dataran rendah Purworejo dan dataran rendah Yogyakarta. Tinggian Kulon Progo dicirikan oleh kompleks gunung api purba yang tumbuh di atas batuan berumur Paleogen dan ditutupi oleh batuan karbonatan (batugamping dan napal) yang berumur Neogen.

Aktivitas magmatisme di daerah Kulon Progo terjadi pada Oligosen - Miosen (van Bemmelen, 1949) dengan penyebaran batuan vulkanik barat - timur. Pada zaman Tersier daerah Kulon Progo diperkirakan telah mengalami deformasi paling sedikit dua kali periode fase tektonik (Sopaheluwakan, 1976; Atmadja dkk., 1994) yaitu pertama terjadi pada Oligosen Akhir Miosen Awal dan kedua terjadi pada Miosen Tengah - Miosen Akhir yang menghasilkan busur magmatik.

Adanya sesar-sesar yang berpola regangan, sesar-sesar naik dan pergeseran busur magmatik dari utara ke selatan kemudian berubah dari selatan ke utara menunjukkan adanya perkembangan tatanan tektonik. Hal ini gaya yang bersifat regangan berubah menjadi gaya kompresi. Gejala ini berkaitan pula dengan perubahan kecepatan lempeng samudera HindiaAustralia terhadap lempeng Eurasia. Evolusi tektonik Jawa selama Tersier menunjukkan jalur subduksi yang menerus dari lempeng HindiaAustralia menyusup ke bawah Jawa (Hamilton, 1979; Katili, 1975). Sedangkan busur magmatik Tersier sedikit bergeser ke arah utara dan busur magmatik Kuarter berimpit dengan busur magmatik Miosen Tengah (Atmadja dkk, 1994) dengan jalur subduksinya bergeser ke selatan (Gambar 4).

Kegiatan magmatik busur kepulauan berumur Tersier di Pulau Jawa diawali sejak 40 - 19 juta tahun yang lalu (Eosen Akhir - Miosen Awal) dan menghasilkan produk berupa jejak sumbu volkanik berarah barat - timur. Produk himpunan batuan yang terbentuk bersifat andesitis dengan ciri afinitas kalk alkali dan sedikit toleit. Kegiatan magmatik kedua terjadi antara $11-2$ juta tahun yang lalu (Miosen Akhir - Pliosen) dengan himpunan batuan yang bersifat kalk alkali andesitis (Atmadja, dkk, 1991). 


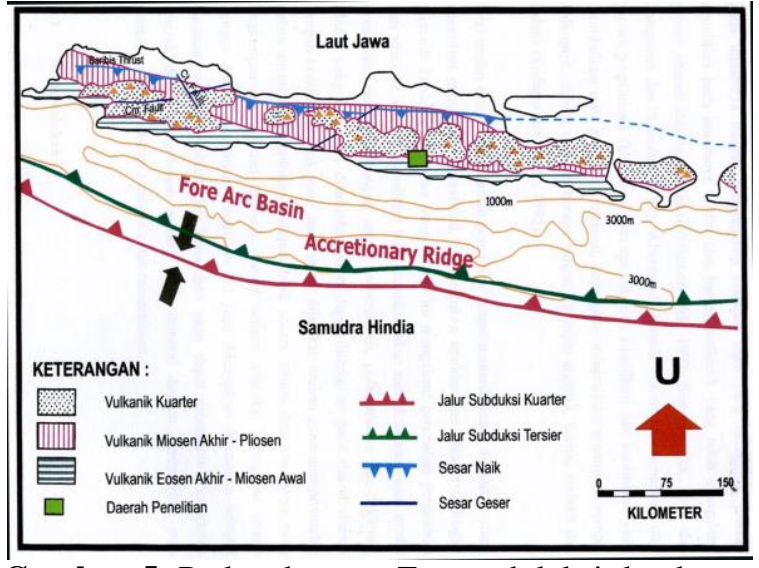

Gambar 5. Perkembangan Zona subduksi dan busur magmatik pada jaman Tersier hingga sekarang (modifikasi Soeriatmaja, dkk 1994; Simanjuntak dan Barber,1996).

Berdasarkan penanggalan radiometri $\mathrm{K}-\mathrm{Ar}$ oleh (Atmadja, dkk, 1991) bahwa umur batuan volkanik di daerah Kulon Progo $42.73 \pm 9.78$ sampai $15.30 \pm 0.88$ juta tahun yang lalu (Eosen Akhir- Miosen Awal) dengan penyebaran batuan volkaniknya ke arah barat - timur (pola struktur Jawa). van Bemmelen (1949) mengatakan bahwa Kubah Kulon Progo merupakan hasil dari undasi kecil (minorundation) yang bentuk kubahnya mempunyai arah timurlaut - baratdaya.

Teori tektonik lempeng yang baru yaitu konsep tektonik lempeng, dimana terdapat hubungan interaksi lempeng, deformasi dan proses magmatisme, pendapat tersebut sudah tidak sesuai lagi sehingga perlu diteliti kembali. Mitchel (1972) mencetuskan konsep hubungan antara tektonik lempeng dengan mineralisasi, salah satu contonya adalah hubungan antara interaksi konvergen busur kepulauan dengan mineralisasi. Pembentukan endapan bijih diperlukan tiga syarat utama yaitu adanya sumber panas yang dapat berupa magma, larutan hidrothermal berupa larutan sisa magma dan channel way dapat berupa ruang antar butiran dan struktur batuan. Selain itu dipermukaan dapat dikenali dengan adanya zona alterasi dan mineralisasi sehingga dengan mempelajari struktur, alterasi, dan tipe mineralisasi akan memberikan suatu informasi yang dapat membantu untuk mengetahui secara langsung aliran larutan dalam sistem hidrothermal.

Perbedaan tipe tektonika akan mempengaruhi tipe struktur utama dan lingkungan pembentukan endapan bijih, contoh breksi pada umumnya sebagai "hosted rock" untuk endapan $\mathrm{Au}-\mathrm{Cu}$ $\mathrm{Mn}$. Temperatur dan $\mathrm{pH}$ larutan merupakan faktor penting yang mengontrol tipe dari alterasi hidrothermal. Dengan mengetahui mekanisme dan transportasi larutan hidrothermal serta pengendapannya maka distribusi endapan bijih dapat diketahui bentuk cebakannya atau modelnya. Model endapan bijih dapat membantu dalam explorasi endapan bijih pada semua tingkatan, baik dalam pengamatan dari tipe endapan maupun kemenerusan arah aliran larutan, yang berarti arah dari endapan bijih yang bernilai ekonomis dapat dilacak. Latar belakang permasalahan yang menarik di daerah telitian untuk mengetahui karakteristik mangan di daerah Kliripan dan sekitarnya, Desa Hargorejo, Kecamatan Kokap, Kabupaten Kulon Progo, Propinsi DI.Yogyakarta karena secara genetik keterdapatannya berbeda dengan genetik mineralisasi emas di daerah Sangon dan sekitarnya, Kecamatan Kokap, Kabupaten Kulon Progo.

Penelitian ini bertujuan untuk mempelajari karakteristik pembentukan mangan di daerah Kliripan dan sekitarnya serta potensi ekonomi dari endapan mangan, berdasarkan kajian di lapangan maupun analisis laboratorium.

\section{METODOLOGI}

Metode penelitian yang digunakan dalam penelitian dapat dibagi dalam empat tahap, yaitu:

1). Tahap Pertama kompilasi dan analisis data sekunder .

2). Tahap kedua adalah pekerjaan lapangan.

3). Tahap ketiga kegiatan laboratorium.

4). Tahap keempat kegiatan di studio.

Tahap Pertama: Kompilasi dan Analisis Data Sekunder

Kegiatan ini bertujuan untuk mempelajari data dari peneliti terdahulu guna mendapatkan gambaran mengenai apa yang pernah dilakukan serta disimpulkan mengenai gejala mineralisasi mangan di daerah penelitian.

Tahap ke dua: Penelitian Lapangan dan Pengambilan Contoh Batuan

Penelitian ini dilakukan untuk menambah dan melengkapi data yang sudah ada untuk mendukung pemecahan permasalahan 


\section{Tahap ke tiga: Kegiatan Laboratorium}

a. Analisis Petrografi

Analisis ini merupakan dasar yang sangat penting untuk menentukan analisis selanjutnya. Dalam analisis ini sebanyak 20 contoh batuan dideskripsi menggunakan mikroskop polarisasi. Analisis petrografi batuan dilakukan untuk contoh batuan yang diambil, mencakup pemerian primer, sekunder serta tekstur batuan. Dengan demikian dapat diketahui nama dan jenis batuan serta himpunan mineral yang ada.

b. Analisis Geokimia Batuan

Analisis Geokimia AAS (Atomic Absorption Spectometry) dilakukan di Pusat Survey Geologi (PSG) sebanyak 6 contoh batuan. Dalam analisis dengan metoda AAS ini bertujuan untuk mengetahui kandungan mangan yang ada di daerah penelitian.

\section{Tahap ke empat: Kegiatan Studio}

Pada kegiatan studio ini penulis mencoba membuat gambar/tabel/foto data lapangan dan hasil analisis laboratorium.

\section{HASIL}

\section{Analisis Petrografi}

Mangan di daerah Kulon Progo terdapat menyebar di dalam lapisan batugamping yang terdapat dalam tuf volkanik dan breksi andesit. Pembentukan mangan di Kulon Progo merupakan mineralisasi sekunder dimana kadar mangannya berkonsentrasi pada zona oksidasi. Mineralisasi mangan yang ditemukan di daerah Kliripan, Hargorejo berupa pocket atau kantung pada batugamping terumbu dan sisipan pada perlapisan batugamping klastik. Hal ini mencirikan bahwa cebakan mangan di daerah Kliripan terbentuk pada lingkungan laut. Mineral ini terlihat jelas secara megaskopis di lapangan butiran utama kristalin kalsit nonfosilan yang dijumpai dalam keadaan tidak sempurna, dibeberapa tempat tampak mineral hitam (opak) hadir mengisi retakan halus dan tersebar merata dengan bentuk tidak teratur, mineral lain yang ditemukan adalah butiran dolomit yang mengambang dalam matriks mikrit. Hasil analisis petrografi dari batugamping ini menunjukkan bahwa mineral penyusun sayatan gamping kristalin, non fosilan, dengan komposisi kalsit dan bentuk kristalnya sudah tidak terlihat karena telah tergantikan mineral lain, semen yang hadir berupa mikrospar kalsit dan sedikit oksida besi. Batuan ini diduga sebagai komponen batupasir konglomeratik yang terlepas karena kondisi matrik yang sudah mengalami pelarutan dan porous (Gambar 6).

\section{Analisis Geokimia AAS (Atomic Absorption Spectometry)}

Hasil analisis ini nantinya berupa kadar mangan pada daerah telitian dalam bentuk presentase, yang nantinya menjadi data utama dalam penentuan persebaran mangan pada formasi batuan di daerah telitian. Untuk lebih jelasnya hasil analisis kimia dapat dilihat pada Tabel 1.

Hasil analisis AAS kandungan unsur mangan yang ada adalah pirolusit, mangaan, psinomelan dan rhodokrosit. Kandungan mangan di daerah Kliripan dan sekitarnya berkisar antara $45,1 \%$ sampai $63,1 \%$. Jenis mangannya adalah mangan sedimenter, sebagian berupa nodul di dalam batugamping klastik dan sebagian lainnya berupa sisipan dalam batugamping klastik.

Secara megaskopis mineral pirolusit merupakan mineral berwarna abu-abu besi dengan kilap metalik, mempunyai kekerasan 22,5 dan berat jenis $4,8 \mathrm{gr} / \mathrm{cc}$. Bersifat masif atau reniform dan kadang-kadang berstruktur fibrous dan radial.

Psilomelan merupakan mineral dengan komposisi oksida. Mineral ini mempunyai warna abu abu besi, mempunyai kekerasan (5-6) dan kilap submetalik. Sebagai mineral yang amorf, psilomelan bersifat masif, reniform, botriodal, atau stalaktitik, sehingga lebih umum dijumpai dalam cebakan sekunder.

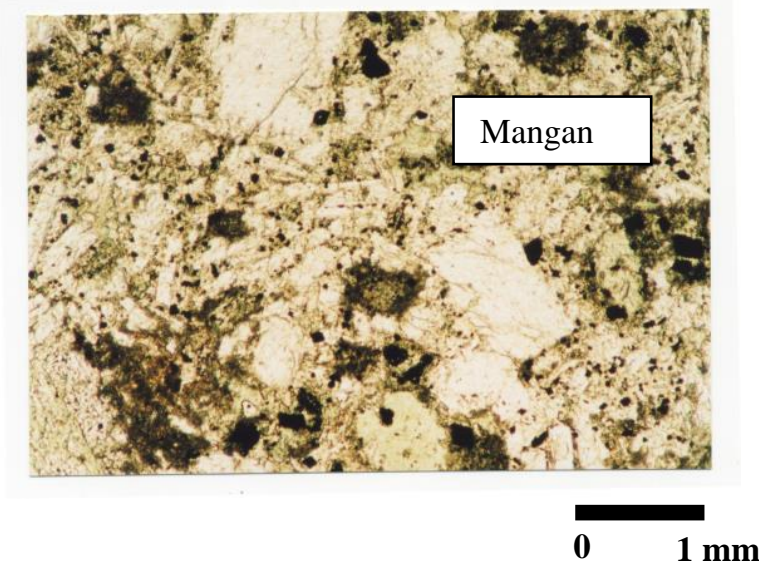

Gambar 6. Sayatan tipis nikol silang mangan (warna opak) yang menyebar di batuan pada lokasi LP.2 daerah Kliripan. 
Tabel 1. Hasil Analisis Kimia Mineral Mangan di Daerah Kliripan dan sekitarnya

\begin{tabular}{cccc}
\hline Lokasi & Mn (\%) & Metode & Keterangan \\
\hline LP.1 & 60,3 & AAS & Sampel yang berupa nodul batugamping. \\
LP.2 & 45,1 & AAS & Merupakan Fragmen dibatugamping. \\
LP.3 & 55,4 & AAS & Sampel mangan yang terdapat berlapis. \\
LP.4 & 63,1 & AAS & Nodul-nodul mangan/fragmen batugamping. \\
LP.5 & 47,5 & AAS & Sampel mangan yang terdapat berlapis \\
LP.6 & 62,1 & AAS & Sampel mangan yang terdapat berlapis \\
\hline
\end{tabular}

Manganit merupakan mineral oksida terhidrasi yang berwarna hitam besi atau abuabu baja. Kedua mineral ini dijumpai dalam urat bijih ataupun cebakan sekunder.

Rhodokrosit yang berkomposisi karbonat, merupakan mineral berwarna merah muda hingga coklat yang terbentuk dalam urat bijih sebagai cebakan replasemen pada batuan kapur. Rhodonit yang berkomposisi silikat mempunyai kemiripan sifat fisik dengan rhodokrosit, namun mineral ini terbentuk sebagai cebakan sekunder.

\section{PEMBAHASAN}

Formasi Kaligesing/Dukuh secara umum disusun oleh litologi : breksi andesit, tuf, tuf lapilli, aglomerat, lava andesit. Himpunan batuan tersebut secara umum disusun oleh mineral-mineral plagioklas, piroksen, biotit dan gelas. Himpunan batuan tersebut berinteraksi dengan larutan hidrothermal sehingga sebagian mineral mengalami ubahan. Batuan ubahan yang terbentuk disusun dalam bentuk zonasi, dimana zonasi yang paling luar (paling rendah) adalah zona filik, zona propilitik dan zona argillik. Selama proses hidrothermal berlangsung maka akan terjadi mobilisasi unsur kimia mineral. Proses mobilisasi unsur tersebut terjadi pada zona ubahan propilitik dan zona ubahan argillik. Andesit daerah Kulon Progo dengan mineralogi plagioklas, piroksen, biotit dan gelas mengalami ubahan hidrothermal dengan menghasilkan himpunan mineral ubahan seperti: serisit, epidot, klorit, illit, kaolinit, monmorilonit dan kuarsa.

Secara umum urutan zona ubahan batuan andesitik tersebut dimulai dari zona yang paling luar yaitu zona propilitik terjadi mobilisasi unsur pengkayaan $\mathrm{Ca}$, di mana plagioklas dan piroksen akan terubah menjadi epidot dan klorit. Sedangkan pada zona argillik terjadi pengkayaan unsur $\mathrm{Al}$, dimana mineral plagioklas dalam kondisi jenuh $\mathrm{H}_{2} \mathrm{O}$ akan terubah menjadi kaolinit. Pada kedua zona tersebut terjadi pengkayaan unsur $\mathrm{Fe}$ dan $\mathrm{Mg}$ dimana mineral klorit berasal dari ubahan mineral biotit, plagioklas dan piroksen. Pengkayaan $\mathrm{SiO}_{2}$ di dalam batuan ubahan disebabkan oleh pengendapan lokal mineral kuarsa di dalam uraturat kuarsa.

Alterasi dan mineralisasi logam di daerah Kulon Progo termasuk dalam Formasi Kaligesing/Dukuh dengan litologinya terdiri dari breksi andesit, tuf, tuf lapilli, aglomerat dan sisipan lava andesit. Formasi Kaligesing/Dukuh ini ciri-ciri litologinya hampir sama dengan Formasi Kebo-Butak di Pegunungan Selatan (Rahardjo dkk., 1995). Selain mineralisasi emas di daerah Kulon Progo juga terdapat mineralisasi bijih, antara lain galena, pirit, kalkopirit, sphalerit, kovelit, molibdenit, barit, magnetit, dan hematit. Batuannya sebagian besar sudah mengalami silisifikasi dan terpropilitisasi. Berdasarkan kesamaan litologinya mineralisasi emas di daerah Kulon Progo kemungkinan ada kemiripannya dengan cebakan emas di daerah Wonogiri (Jawa Tengah) dan cebakan emas di daerah kompleks Kubah Bayah (Jawa Barat), karena ketiga lokasi ini termasuk dalam satu jalur magmatis yang berumur sama (Oligosen Miosen).

Di atas Formasi Andesit Tua diendapkan secara tidak selaras Formasi Jonggrangan dan Formasi Sentolo. Formasi Jonggrangan dicirikan oleh napal tufaan dan batupasir gampingan dengan sisipan lignit. Di bagian atas berubah 
menjadi batugamping berlapis dan batugamping terumbu. Sedangkan Formasi Sentolo bagian bawah dicirikan oleh perselingan batulempung dan batupasir. Kemudian kearah atas berubah menjadi napal sisipan batupasir dan tuf. Bagian atas dari formasi ini dicirikan oleh batugamping berlapis dan batugamping terumbu.

Secara megaskopik, Psilomelan memiliki ciri-ciri berupa warna hitam, tidak tembus cahaya (opak), kilap submetalik, gores nya hitam atau coklat, dan kekerasan 5-7 skala mohs. Sebagai mineral yang amorf, psilomelan bersifat masif, reniform, botriodal, atau stalaktitik, sehingga lebih umum dijumpai dalam cebakan
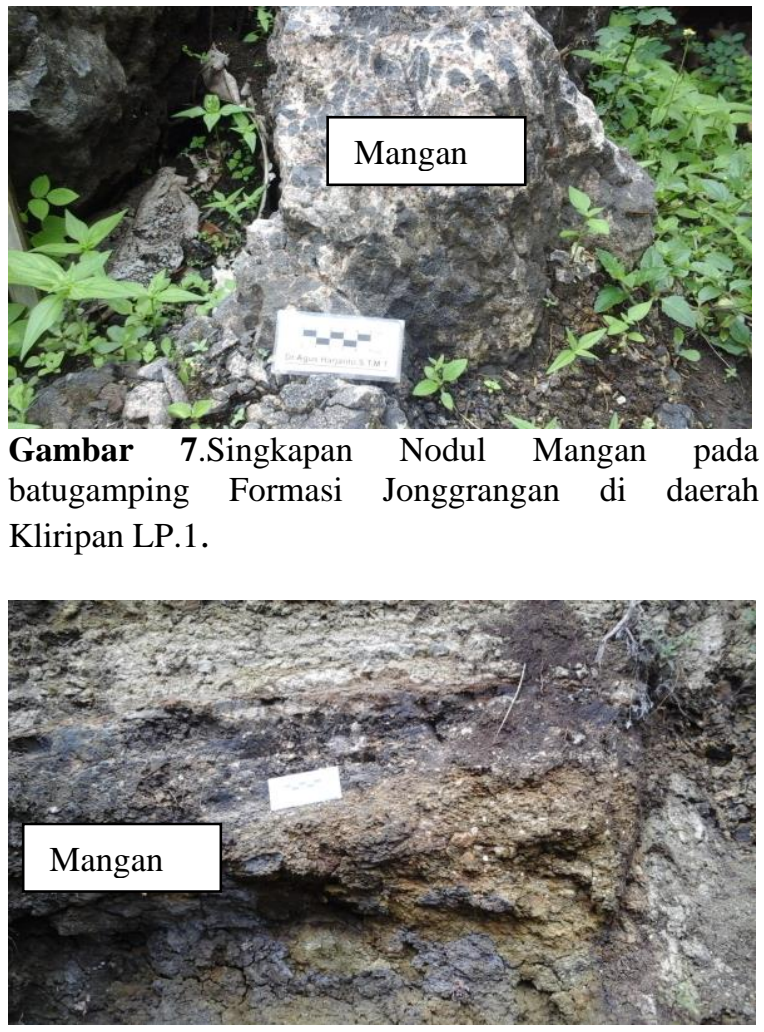

Gambar 8. Singkapan Sisipan Mangan pada batugamping Klastik Formasi Jonggrangan di daerah Kliripan LP.3.

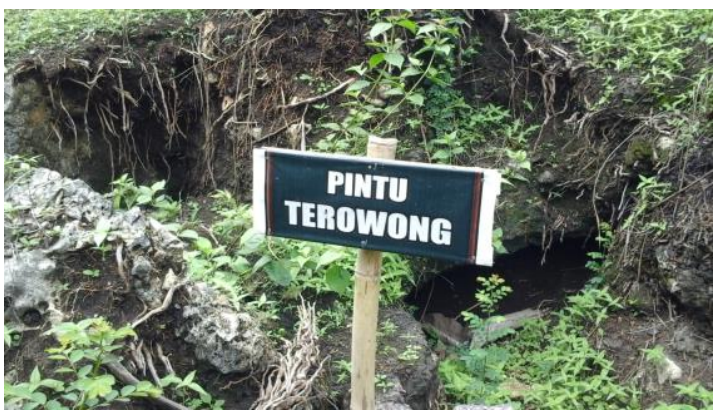

Gambar 9. Pintu masuk terowongan penambangan mangan pada jaman Belanda di daerah Kliripan LP.6 sekunder (Gambar 7)

Beberapa mineral mangan yang dijumpai terbatas dalam cebakan bijih adalah hausmanit, todorokit, lithioforit, dan nsutit. Hausmanit secara megaskopik memiliki ciri mineral berwarna coklat kehitaman dengan kilap submetalik. Nsunit pada pengamatan megaskopik merupakan mineral berwarna merah muda hingga coklat yang terbentuk dalam urat bijih sebagai cebakan replasemen pada batuan kapur (Gambar 8.)

Pada daerah telitian terdapat pintu masuk terowongan bekas penambangan mangan jaman Belanda yang membuktikan bahwa terdapat mineralisasi mangan pada daerah penelitian. (Gambar 9)

Hasil analisis AAS kandungan unsur mangan yang ada adalah pirolusit, mangaan, psinomelan dan rhodokrosit. Kandungan mangan di daerah Kliripan dan sekitarnya berkisar antara 45,1\% sampai $63,1 \%$. Jenis mangannya adalah mangan sedimenter ada yang nodul di dalam batugamping klastik dan ada yang berupa sisipan dalam batugamping klastik.

Dari hasil penelitian ini tidak ada hubungan pembentukan alterasi dan mineralisasi emas di daerah Sangon dan sekiatarnya Kecamatan Kokap, Kabupaten Kulon Progo dengan pembentukan mangan di daerah Hargorejo dan sekitarnya Kecamatan Kokap, Kabupaten Kulon Progo. Secara genetik pembentukan alterasi dan mineralisasi emas di daerah Sangon berkaitan dengan proses hydrothermal sedangkan genetik mangan di daerah Hargorejo dan sekitarnya terbentuk secara sedimenter

\section{KESIMPULAN}

Daerah Kliripan dan sekitarnya terdapat daerah prospek mineral mangan yang berupa nodul pada batugamping klastik Formasi Jonggrangan dan beberapa terdapat berupa mangan berlapis baik sebagai sisipan pada batugamping klastik Formasi Jonggrangan.

Satuan Batugamping Formasi Jonggrangan, merupakan satuan batuan yang mempunyai prospek terdapatnya mineral mangan yang bernilai ekonomis dengan kadar mangan daerah penelitian antara $45,1 \%$ sampai $63,1 \%$. Pada daerah telitian terdapat 4 macam jenis mangan yaitu pirolusit, mangaanit, psilomelan dan rhodokrosit yang secara genesa terbentuk secara sedimenter. 


\section{UCAPAN TERIMAKASIH}

Penulis mengucapkan terimakasih kepada Universitas Pembanguan Nasional "Veteran" Yogyakarta yang telah membantu dana penelitian ini sehingga penulis dapat menyelesaikan laporan penelitian ini.

\section{DAFTAR PUSTAKA}

Asikin, S. 1974. Evolusi Geologi Jawa Tengah dan sekitarnya ditinjau dari segi Tektonik Dunia yang baru, Disertasi doktor, Institut Teknologi Bandung, tidak dipublikasikan, 103.

Atmadja, S., Maury R.C., Bellon H., Pringgoprawiro H., Polve M., Priadi B. 1991. The Tertiary Magmatic Belts in Java, Proceeding Symposium On Dynamics of Subduction and it products, The silver Jubilec Indonesian Institute of Science (LIPI), hal.98121

Hamilton, W., 1979. Tectonic of the Indonesian Regions, United States Geological Survey, Proffesional paper No.1078, Washington, 1842.

Katili, J.A. 1975. Volcanism and Plate Tectonics in the Indonesia Island Arcs. Tectonophysics, 26(3-4), hal.165-188.

Rahardjo, W., Rumidi, S. dan Rosidi, H.M.D. 1995. Geological map of the Yogyakarta Quadrangle, Java, skala 1:100.000, Geological Survey of Indonesia.

Sopaheluwakan, J., 1976. Critiques and a new perspective on basement tectonic studies in Indonesia : a review of current results and their significance in geological exploration. Proceedings of the 30th Anniversary Symposium, Research and Development Centre for Geotechnology, hal.163-175.

Sujanto, F.X. dan Roskamil. 1975. The Geology \& Hydrocarbon Aspects of the South Central Java. Prosiding Pertemuan Ilmiah Tahunan Ikatan Ahli Geologi Indonesia.

van Bemmelen, R.W. 1949. The Geology of Indonesia Vol. IA. The Haque Martinus Nijnhoff. 